\title{
CIVIL SOCIETY ORGANISATIONS, INCOMPETENT CITIZENS, THE STATE AND POPULAR PARTICIPATION IN TANZANIA
}

\section{Ernest T Mallya}

Earnest T Mallya is Associate Professor in the Department of Political Science and Public Administration, University of Dar es Salaam, Tanzania e-mail: etmallya@duce.ac.tz; ermallya@yahoo.com

\begin{abstract}
Civil society organisations have played a vital role in the relationship between the state and society. In Africa they have come into existence for different purposes, ranging from 'self-help', where the state has failed to help its citizens, to human rights, as the wave of democratisation has peaked, and economic rights, when a country's economy has crashed and governmental capacity declined to the extent that the population has had to take care of itself without help from the government. In Tanzania CSOs have had to play a more extensive role because many citizens are not politically competent and CSOs have had to take the lead in strengthening the demand side of the political equation. But this role is questionable in cases where CSOs have taken to speaking for and representing people in many forums without the consent of those they claim to represent. In the process CSOs, like NGOs, have compromised their autonomy, becoming close allies and partners of the state. The dilemma is that if they do not do this they cannot help the people they purport to help and if they do they are seen to be usurping the power of the people. The way forward is to empower citizens to assume their role as citizens and to ensure that the relationship between CSOs and the state remains beneficial to all.
\end{abstract}

\section{INTRODUCTION}

Civil society organisations (CSOs) are groups set up to assist members of civil society (the space between individuals and the government) in a variety of ways, including politically, socially, and economically. CSOs in general can be divided into formal and informal. The former would include such organisations as labour unions, which adhere to codified rules and require governmental sanction to 
operate. The latter are groups of individuals who cooperate in various ways for the benefit of their own communities, offering collective action, financing, and the provision of services. Examples of these are neighbourhood vigilante groups, user groups, and informal support groups such as burial societies.

Some civil society organisations (non-governmental organisations - NGOs) act as go-betweens in the interaction between the state and society, others are community based and will be referred to here as community-based organisations (CBOs).

NGOs vary widely in terms of mandate, size, and resources. Mercer (2002, p 6) offers the following distinction between NGOs and CBOS, although for the latter she uses the term grassroots organisations (GROs):

The term 'NGO' is understood here to refer to those organisations that are officially established, run by employed staff (often urban professionals or expatriates), well-supported (by domestic or, as is often the case, international funding), and that are often relatively large and well-resourced ... They are seen as different from Grassroots Organisations (GRO) that are usually understood to be smaller, often membership based organisations, operating without a paid staff but often reliant upon donor or NGO support, which tend to be issuebased and therefore ephemeral.

The main distinctions within the NGO family are between advocacy NGOs, which are concerned with influencing public policy, and service NGOs, which are concerned with social service delivery. The latter tend to be more permanent. Van Tuijl (1999, p 499) refers to service delivery NGOs as 'operational' NGOs. Clark (1991, pp 40-41) delineates five types of social services-delivery NGOs: relief and welfare agencies such as Catholic Relief Agencies (CARITAS); technical innovations organisations such as the International Aga Khan Foundation; organisations concerned with public service contracts, such as CARE International, which is funded by the developed world but works in the developing world; popular development agencies such as OXFAM; and grassroots-based organisations registered as NGOs and working for particular local communities. There are other ways of classifying NGOs, but, for the purposes of this paper, the above will suffice.

A strong and active civil society is the foundation on which rest the four pillars of governance: transparency, accountability, participation and the rule of law (Asian Development Bank - ADB 2000, p 555). Mwaikusa (1996, p 79) notes that CSOs are necessary to the control of governments. It has also been noted that the root cause of most state-civil-society confrontations is the feeling that 
stakeholders are alienated from the decision-making processes that affect their livelihood. It would therefore seem that many civil society organisations help address social exclusion and democratic deficit. ${ }^{1}$

\section{PARTICIPATION}

\section{The concept}

Participation, in our context, is the way power and responsibility are shared among the state and the different social groups and classes in the process we call 'development'. Development, in this context, is qualitative and quantitative social transformation, in directions participants consider favourable, brought about by internal and external forces. For this transformation to happen there must be predefined social, economic, and political goals.

In many societies a minority of the people shares most of the power and wealth, while the majority remains powerless and wretched. The result is that many view the concept of participation as involving some type of confrontation between the powerful and the powerless, the wealthy and the poor. This is more so because, in many cases, the word participation is used in conjunction with another term, 'popular', suggesting that those who are powerless will be given a greater say in and greater control over decisions, resources, and so on and those who have been excluded must now be included in some key processes.

The conception of popular participation as essentially the struggle by the disadvantaged to gain greater control over the resources and institutions they depend upon for their living is very close to the reality. Participation by all in making the decisions that most affect their lives, along with holding leaders accountable, and the enjoyment by all groups and individuals of basic human and civic rights, is the essence of democracy.

Genuine popular participation in development requires democratic organisation; in our case, these organisations are, in most cases, either local governments or those civil society organisations that concentrate their activities at the local level. Thus, popular participation is best seen as the changing relationship between the relatively powerless and the powerful in an encounter in which the powerless become more powerful. To ascertain how much participation there is, one must assess the degree to which the formerly all-powerful take into consideration, on a day-to-day basis, the aspirations and rights of those who have previously been powerless to influence decisions about the process of development.

1 The ADB defines democratic deficit as the lack of voice to the people beyond electoral franchise and periodic elections'. 
It is now recognised that the success of development programmes and projects depends on participation by the stakeholders (in our case the poor, who are normally sidelined) in all stages of development. One method used in rural areas in pursuit of this key element is participatory rural appraisal (PRA), a process of assessing poverty, identifying needs, and charting ways to address those needs.

PRA has been described as 'a growing family of approaches and methods which enable local people to express, enhance, share and analyse their knowledge of life and conditions, to plan and act' (URT/UNDP 1998, p 4). PRA involves a variety of tools, used to gather and share information and to instil in all the participants values such as the need to listen rather than to impose their views on others, to facilitate rather than dominate, to elicit opinion from all members of a group, and to allow a process to take its own path rather than to follow a prescribed sequence.

\section{Participation: The continuum between top-down and bottom-up approaches}

\begin{tabular}{|l|l|l|l|l|}
\hline & $\begin{array}{l}\text { Traditional } \\
\text { participation }\end{array}$ & $\begin{array}{l}\text { Consultative } \\
\text { participation }\end{array}$ & $\begin{array}{l}\text { Partnership } \\
\text { participation }\end{array}$ & $\begin{array}{l}\text { Transformational } \\
\text { participation }\end{array}$ \\
\hline $\begin{array}{l}\text { Political } \\
\text { dimensions }\end{array}$ & $\begin{array}{l}\text { Does not } \\
\text { challenge the } \\
\text { existing power } \\
\text { structure }\end{array}$ & $\begin{array}{l}\text { May result in } \\
\text { reform of the } \\
\text { existing power } \\
\text { structure }\end{array}$ & $\begin{array}{l}\text { Balance of } \\
\text { power should } \\
\text { be equal }\end{array}$ & $\begin{array}{l}\text { Challenges the } \\
\text { existing power } \\
\text { structure }\end{array}$ \\
\hline Methods & $\begin{array}{l}\text { Training and } \\
\text { visitation }\end{array}$ & $\begin{array}{l}\text { Diagnosis and } \\
\text { designing }\end{array}$ & PRA, PPA, ${ }^{*}$ etc. & $\begin{array}{l}\text { Political activism } \\
\text { (kind of revolu- } \\
\text { tion?) }\end{array}$ \\
\hline $\begin{array}{l}\text { Agenda } \\
\text { setters }\end{array}$ & $\begin{array}{l}\text { Agenda set by } \\
\text { outsiders }\end{array}$ & $\begin{array}{l}\text { Agenda set by } \\
\text { outsiders }\end{array}$ & $\begin{array}{l}\text { Agenda set } \\
\text { jointly }\end{array}$ & $\begin{array}{l}\text { Agenda set by } \\
\text { challengers }\end{array}$ \\
\hline
\end{tabular}

${ }^{*} \mathrm{PRA} \quad=\quad$ Participatory rural appraisal

${ }^{*} \mathrm{PPA} \quad$ = Participatory poverty assessment

\section{Why popular participation?}

Popular participation should be encouraged because in order to have rapid and sustainable development the creativity and energies of all groups and classes in society must be liberated and the exclusion of some important groups from the development process results in social tensions and conflicts. The result is that the state gradually loses legitimacy, which may result in chaos and, in turn, arrest development. In such a case only new political and institutional reforms will allow the process to resume. 
'Popular participation' implies that some groups will lose power to others in this case it is the few with the greatest power who must surrender some to the many. That is why the word 'popular' is used in conjunction with participation. Popular participation may bring into the open latent conflicts that have long been suppressed and may thus be seen as being counterproductive. What needs to be done in such a situation is to make the kinds of compromises that will reassure those who were, until recently, excluded from the decision-making processes that their interests will be taken care of in the long term.

\section{POPULAR PARTICIPATION AND CITIZEN COMPETENCE}

Politically competent citizens may participate in the politics of their country at all levels. Competent citizens are those who are aware of what is going on in their country and who try to be part of the political processes taking place, actively participating in elections, policy discussions, political debates, and so on. This competence must be nurtured and, in most cases, the nurturing depends on the dominant political culture of a country or a section of a country.

Civic education has been recognised as an essential strategy for the development of civic competence among the citizens in a democracy. Prior to the adoption of the multiparty political system in Tanzania, for example, civic education was delivered in the form of political education for the youth in schools and colleges, and for adults through adult education, popular campaigns for economic and social development, and through radio broadcasts. It was also available in print in books and in government- and party-owned newspapers.

The approach tended to give a one-sided representation of the story, devoid of critical analysis, with differing or contradictory perspectives censored. The purpose of the political education programmes was to mould the behaviour of citizens so they accepted unquestioningly the then one-party ideology of socialism and self-reliance. Tanzania's current acquiescent political culture and the low level of civic competence are the result of such programmes.

The 1991 Presidential Commission (Nyalali) Report on whether Tanzania should adopt a multiparty political system recommended, among other things, that a constitutional conference be convened and a programme of national civic education be established in order to instil in the public a democratic political culture. One of the results of the commission's proposals was the emergence of civil society organisations dealing with civic education. The argument for civic education programmes and activities in Tanzania arises from three decades of experience of single-party rule. It is clear from research done by such CSOs as Research and Education for Democracy in Tanzania (REDET) that the level of civic competence among the Tanzanian electorate is still very low. 
A situation analysis conducted by REDET (Mushi, Baregu \& Mukandala 2001) confirms the absence of a democratic political culture. This means that much of the electorate is unaware of its rights and obligations. Its participation in local government affairs and membership of civic organisations is low, as is its participation in such civic activities as elections (Gasarasi 2001, pp 148-68). Similarly, a large proportion of citizens were found to be politically incompetent, in that they could not intervene in bad local governance by taking such actions as opposing the government or by complaining through collective action.

Other findings of the survey suggest a predominance of conservative voting patterns and that many people vote for reasons that have nothing to do with the desire to influence policies. It was further established that participation in civic organisations was still in its infancy, with the motivation to join driven by the wish for survival. Baregu (2001, pp 129-47), for example, observes that, although political competence among citizens at local level is higher than that national level, it is low at both levels in a political culture in which citizens rarely demand but request and cajole the government to carry out its rightful duties. He recommends the development of programmes to address the problems, with a view to enhancing popular capacity to control public power.

\section{WHAT SHOULD THE ROLE OF CSOs BE?}

It is fashionable for people from different walks of life to talk of the cooperation between governments and CSOs and, especially, NGOs. Whereas some see this as good for society, others do not - and they may have a point. One such sceptic about the close relationship between governments and CSOs is Shivji (2003, pp 2-3), who launches a scathing attack on NGOs that have come to 'lose their sight' of what they should be, what they should be doing, and what they should not be doing.

He terms this blurring of roles 'participation by substitution', implying that NGOs, contrary to their belief that they are helping the 'people' participate in the policy-making process, are, in fact, alienating core stakeholders. A dilemma arises, however, in a situation where the people are incompetent and CSOs fill the gap, maintaining some interaction between civil society and the government. Shivji, on his part, accuses CSOs (and more specifically NGOs) of a number of actions he believes are contrary to what should be happening in the policy process. He maintains that:

- NGOs have participated in donor-driven policy, which is one manifestation of loss of self-determination by the recipient/developing countries. In so doing NGOs are legitimising this type of domination, 
which goes by the brand name of 'globalisation';

- by pretending to be partners in the policy process NGOs have let governments off the hook, allowing a government to 'abdicate its primary obligation' - to make policy;

- NGOs cannot claim to represent the 'people' - many of those able to negotiate with the government are elite bodies who claim to speak on behalf of the population? NGOs are not elected representatives, nor are they mandated to represent the people.

In the following part of the paper we look at state-CSO relations over time and return to Shivji's criticisms, assessing the chances of citizens participating fully in the policy processes in which the CSOs seem to 'fill' a gap.

\section{THE RISE OF CSO ACTIVITY IN TANZANIA}

Civil society organisations in Tanzania predate the arrival of the colonialists (Chazan, Mortimer, Ravenhill \& Rothchild 1988, p 73), with Welch Jr (2003), for example, dating the creation of human rights NGOs in Africa back to 1839, when they fought slavery on the continent. With the arrival of missionaries and their proselytising activities, other NGOs emerged, in most cases working with the colonial administrations.

Then came the self-help CSOs, which catered for the economic and social adjustments of their members, who were variously affected by, among other things, urbanisation, the monetary economy, and labour migration. The later CSOs were to be the forerunners of the 'professional' and trade associations that would be formed at a later stage, mostly in urban settings, but also on plantations. Some of these associations later took on a political agenda, leading to some becoming nationalist movements. Kiondo (2001) notes that 'associational life in pre-colonial Africa was based on traditional values of sharing and helping each other within the context of extended family, neighbourhood, clan and even beyond'. The coming of the colonial powers and the institution of the state structures we know today marked a new arrangement as far as the civil organisations were concerned.

The type of regime in most pre-colonial societies was governed by different rules and relationships with civil society organisations than was the colonial state, which evolved structures - political, economic, and even social - which 'interfered' with the way life in general was conducted. Most of the 'disturbance' came from the imposition of new economic relations, starting with the monetarisation of the economy and its corollary - taxation.

Social life changed with urbanisation and with the creation of economic zones (plantation and mining), labour reserves, and so on. With the coming of 
the colonial state there was a general shake up of both the nature of civil society organisations and the way they worked.

From the above it is clear that there has always been and always will be some interaction between the state and civil society organisations. The state has always had to relate to society - its very emergency has to do with society. However, the state sets the rules, oversees their application, and takes 'corrective' (or destructive) measures when it feels that the 'correct' path is not being taken. The key difference between political organisations before the coming of the colonialists and after is the fusion of what would have been the state and the 'governor' (chief, king or any other ruler of a given society). Louis XIV's proclamation 'l'état c'est moi' sums up this situation. But with developments there was the separation between the person (the sovereign) and the state, with the state creating institutions to act on its behalf.

The increased CSO activity in Africa in the 1980s and 1990s can be linked to two main factors. The first is the degeneration of the capacity of the state, which has left the people to 'cater for themselves'; the second the disaffection of the population with economic development models which failed to work in their favour. Let us briefly discuss these two factors. On the African continent the degeneration of state institutions in the 1970s and 1980s led to the erosion of a state's capacity to deliver its classical outputs of social services and infrastructure conducive to socio-economic development, law and order, and so on. According to Olowu (2003, p 299) this capacity includes the 'delegative capacity', which is concerned with 'the state's involvement of its citizens from outside the state in the management of the public sector through devolution of responsibilities to local self-governing and non-governmental entities'.

In some countries the situation was so bad that citizens saw no reason to interact with the state, avoiding it as it became irrelevant (see, eg, Gordon 1992, p 77). Tanzania was no exception and this phenomenon of reduced state capacity accounted to a large extent for the resurgence of civil society organisations from the mid-1980s onwards.

Having said that, we need to mention the fact that the process of liberalisation - of politics and economy - led to the weakening of some civil society organisations, including cooperative societies and trade unions, which once mediated between society and the state.

In many African countries these two institutions were 'captured' by the state on the pretext of creating stability and nationalist consolidation of power in the post-colonial governments. As such, they were not as independent as they should have been, but they nevertheless acted on behalf of their members in difficult circumstances and there was some coherence, as well as state support from time to time, which made them look solid and united. 
Their orientation towards their members depended, in many cases, on the type of leadership and issues at stake. Liberalisation weakened them in various ways. Among these were: the new freedom, which led to some members of umbrella organisations withdrawing to create other umbrella organisations; the loss of membership contributions through retrenchment of members due to reforms in the public and parastatal sectors; loss of income from crop-marketing activities by cooperatives due to the intervention of the private crop buyers; and the withdrawal of government support and guarantor status.

This led to the creation of space for smaller, sometimes more informal civil society organisations working at grassroots level, which is significant because it is at the local level that civil society is most readily mobilised around local issues. Linked to the resurgence of CSOs is the alternative development (AD) movement. ${ }^{2}$

The approach of this movement emphasises:

- autonomy in decision-making for territorially organised communities;

- local self-reliance;

- direct (participatory) democracy;

- experiential social learning

Friedman 1998, p vii

AD sought and still seeks to change structures to allow the disempowered to be included in political and economic processes and have rights as citizens and human beings. This is where CSOs become the automatic and most likely alternative channel for voicing the demands of the voiceless. It would imply that AD aims to empower the disempowered, a point also made by Salamon, Solokowski \& List (2003) when they observe that CSOs are 'empowerment-oriented'.

\section{CSO-STATE RELATIONS: LIFELINE, SYMBIOSIS, OR KISS OF DEATH?}

It is worth starting this section with a comment on the involvement or noninvolvement of CSOs in politics. There is a general regulation in Tanzania that CSOs - and especially NGOs - should not engage in politics. Since this section, and the article in general, is concerned with the relationship between the statewhich is an organ of power - and the CSOs it is appropriate to consider whether it is possible to interact with the state without being involved in power play.

2 This movement came into being after militants became disaffected by the mainstream development specialists of the time, which (until the 1970s) emphasised rapid cumulative growth, urban bias, and single-minded pursuit of industrialisation. 
Politics is all about power and when we define power it becomes obvious that CSOs cannot avoid politics. Whether one defines power as 'the capacity to change the probability of outcomes' (Dahl 1961), 'politics as who gets what, when, and how' or 'the participation in decisions about severe sanctions, that is about major rewards and deprivations' (Lasswell 1958), or 'the ability to make things happen that would not have happened otherwise' (Deutsch 1970), we can see that civil society is right - there is politics!

In terms of David Easton's input-output model civil society is the source of the inputs - including demands and support - which are part and parcel of the political system. Whichever way one may want to look at it, there is no way CSOs can absent themselves from politics and it would seem that the NGO Act of 2002 acknowledges that fact in the absence of explicit provisions barring NGOs from engaging in political activity, although the Act does state that they should remain non-partisan when it comes to political affiliation.

Thus, when a CSO/NGO campaigns for a political party it is seen to be breaking a key principle of the CSO law. The problem, however, is one of interpretation. The agendas of a CSO and those of a given political party may be the same or similar, or may overlap. It would be easy for those opposing CSOs to interpret that as being deliberate support for the party's agenda.

Despite the issue of politics CSOs have the potential to help the government to perform its duties, or be seen to perform its duties, better. This is more so when we consider that the explosion of CSO numbers in the aftermath of the economic crises of the 1970s and 1980s was due to the virtual breakdown of the social services networks as supported by incapacitated governments.

CSOs can help government deliver services more efficiently and effectively by identifying target groups, facilitating their access to the services on offer, and even coordinating the delivery of services from various sources. NGOs are known to have reached people where governments have failed, especially in developing countries where infrastructure is poor, or for some political reason. And, most importantly, CSOs can provide checks and balances on abuse of power at different levels of the 'implementation structure'.

The relationship between CSOs and the state has undergone a number of twists and shifts, of course, depending on the state(s) in question. Traditionally, and as some CSOs (and particularly NGOs) see themselves even now, there should not be too close a relationship between them and the state if they are to do a good job. As Jjuuko (1996, p 194) observes, some independent NGOs regard themselves as diametrically opposed to the state, or at least as sometimes being incompatible with it. As is evident below, this does not necessarily need to be the case. On the other hand, Kirsten (2004, p 16) remarks that civil society and NGOs, in trying to influence governmental action and policy, have had to 
engage the state in different ways. Some have entered into formal partnerships with governments to develop policy jointly, some have acted as consultants to governments, and some have remained outside of any contractual arrangement with government and have chosen to act in a more traditional way, influencing policy through advocacy strategies.

Kiondo (2001) envisages three scenarios for state-CSO relationships. The first is the situation where the state sees the CSOs as partners in development and other state activities, and therefore regards them as supportive of the state. In most cases, these activities relate to social welfare and advocacy.

In Tanzania many CSOs fall into this category, with faith-based CSOs and NGOs in particular having played an important role in health and education since the pre-independence era. A clear example is the conversion of hospitals belonging to religious organisations into district-designated hospitals.

Despite such co-operation there have been times when faith-based NGOs and CSOs have had problems with the state. During the socialist era in Tanzania and, more specifically, during the nationalisation exercise after the promulgation of the Arusha Declaration in 1967, many religious organisations 'lost' their properties including schools, hospitals, and even land - to the state. However, the problems the government faced in running these facilities resulted in their being returned to their original owners when the economy was liberalised. However, some church schools-turned-government schools could not be returned because the student community had become religiously mixed and because of the investment by the government in these facilities since their nationalisation.

Another example of CSOs cooperating with the state is the many advocacy CSOs, which are in the government's good books. Among these are those that deal with HIV / AIDS campaigns in communities, performing a role government cannot play alone given the resources that are needed and the scope of the exercise countrywide. Other examples are organisations working in the areas of environmental protection, civic education, and good governance. In these cases the 'symbiotic' relationship has often been a 'lifeline' to the CSOs, with government facilitating the availability of funds.

The second scenario is where the state feels its interests are threatened by the activities of CSOs in situations, for instance, where the CSOs are providing a political platform - whether real or imagined - for opponents of the government. Unfortunately, in Tanzania, as elsewhere in Africa, most NGOs/CSOs that deal with human rights and gender sensitisation are viewed by the state as opponents. This has been explained by the fact that while the state is supposed to be the guardian of human rights it is frequently the greatest violator of these rights.

In Tanzania, for example, civil society organisations have made their members and other beneficiaries aware of their rights and urged them to 
demand these rights from state organs, actions that are, in many cases, regarded as confrontational. In post-independence Tanzania there has been a 'political honeymoon' in that the political culture of the country did not mould a population that was critical of its leaders.

It was, in the words of Almond \& Verba (1963), a parochial-subject culture, in which the majority were on the 'parochial' side of the continuum. Now that people are demanding their rights government feels threatened and has put in place mechanisms to enable it to remain in power and to keep such groups in check. These mechanisms include licensing and registration conditions, cooption, and even the banning of some NGOs.

A classic case in Tanzania is the Baraza la Wanawake Tanzania (Bawata), the aim of which was to unite all Tanzanian women in the aftermath of plural politics, whereby each political party had a women's wing - which was seen as dividing women. In 1995 Bawata was involved in electoral campaigns, for example, advocating the support of candidates who cared for the rights of women.

The organisation did not last long. After its mobilising activities during the 1995 elections the government accused it, among other things, of being run like a political party and of not submitting its annual accounts to the relevant authority. The latter accusation was rebutted by the Norwegian Embassy in Dar es Salaam, which partially funded Bawata's activities and maintained that the organisation regularly submitted its audited accounts.

However, the government deregistered Bawata on 30 June 1997, claiming that it failed to comply with the provisions of the Societies Ordinance Cap 337 of 1954. It was 'advised' that it could start a fresh registration process after making changes to its constitution and holding elections for new office bearers. ${ }^{3}$ From statements made by senior politicians, among them the country's president, it is clear that the government did not welcome the creation of Bawata as an autonomous national women's organisation. ${ }^{4}$ In such a situation, a close relationship between a human rights CSO and the state will prove to be the 'kiss of death', as the state will ensure that the organisation's agenda is derailed, or, if the organisation is particularly stubborn, it might be put out of business entirely.

The third scenario is the one in which the state feels that the activities of a CSO/NGO place national security at risk, frequently because of the sources and levels of funding of the organisation. When funding comes from outside the country and the amounts involved are viewed by the state as too large questions are raised, the activities of the organisation are monitored, and problems arise when there is contact between the organisation and the state. Again, the

3 See 'Mwambulukutu Afafanua Hatua ya Serikali: BAWATA Iliendesha Shughuli Kisiasa', Uhuru 7 December 1996, p 1.

4 See 'BAWATA Waonywa: Acheni Kujihusisha na Siasa - Mwinyi', Uhuru 19 September 1995, p 3. 
organisations most likely to fall into this category are quasi-political NGOs including human rights organisations and those created for specifically political purposes such as election observation and monitoring.

The interaction between CSOs and the state includes the recent move on the part of some donors and aid agencies to use CSOs as channels of development aid, viewing such a move as a way of rebuking dictatorships and reducing corruption. This would usually lead to the government attempting to exercise control by introducing regulations, using as a pretext 'national security' interests. One way of doing this is to formulate a NGO policy and enact a NGO law to address some of these issues in a way that restricts the free operation of CSOs and NGOs. CSOs need to be 'vigilant' about this type of relationship, too, as working closely with the government can cost them their very existence.

There is not always a clear cut division between the three categories of stateCSO relationship. There are instances where a particular issue will determine the response of the state. For instance, when the Tanzania Media Workers Association (TAMWA) campaigned for children's and women's rights the state was supportive because the campaign was in line with its own policy. TAMWA has, for example, worked very cordially with the Ministry of Community Development, Gender and Children when it comes to implementing its mission, which is 'to use the media to sensitize society on gender issues and advocate and lobby for policy and legal changes which favour the promotion of the rights of women and children'.

Given that Tanzania is a signatory to the International Declaration of Human Rights, the Convention for the Elimination of All Forms of Discrimination Against Women, the Convention on the Rights of Children, and the SADC Platform of Action, there was little chance that the state would be at loggerheads with TAMWA's aims. It is not certain that the cordial relationship with the state would be maintained if the same NGO campaigned for and raised women's awareness of their rights and obligations in the political system.

There are instances when the state has consulted with CSOs about policy issues. Such was the case when the government was preparing the NGOs, Sexual Offences and Land Bills. Such NGOs as the umbrella Tanzania Association of Non-Governmental Organisations, HakiElimu, ${ }^{5}$ the Tanzania Gender Networking programme, the Legal and Human Rights Centre, and the Tanzania Media Women Association spearheaded the campaign for public hearings by the parliamentary committees involved in drafting these Bills.

However, there are also instances where the same CSO that was once the darling of the state becomes an adversary of some sort and, therefore, unwanted. An example in Tanzania is the case of the cooperatives, institutions which emerged

5 Haki in Swahili means 'right to' while Elimu means 'education'. 
during the colonial era, largely to protect peasant farmers from middlemen and other crop purchasers. Different types of cooperatives also emerged in urban areas. After independence the government tried to support cooperatives - especially through unions which unified peasant cooperative societies - but it ended up interfering too much in their affairs. In the end they were, for some reason, seen by the state as a threat and, in 1975, they were abolished.

One of these cooperatives was the Kilimanjaro Native Cooperative Union, which had accumulated wealth and was advancing the interests of the peasants in such a way that the independence government thought it needed more control in order to create, among other goals, 'even development' all over the country. In place of the unions the government introduced pan-territorial parastatals called crop authorities, which, for a number of reasons, failed dismally (see, eg, Ellis 1988; Lofchie 1989; Ponte 2002).

In 1982 the government decided to reintroduce cooperatives both as a way of increasing production and as a way of controlling the peasants, especially when it came to taxation. Contrary to cooperative principles - such as economic viability - the government established cooperative societies in all villages in the country on the pretext of helping peasant production. The cooperatives were generally used as vehicles for government agricultural policy, as well as an effective means of taxing peasant production.

The other civil society organisations that were used by the state were the trade unions, through their umbrella organisation. Immediately after independence the government instituted control over these organisations as a means of consolidating power and advancing the developmentalist philosophy that guided its socioeconomic policy.

The name of the umbrella organisation changed several times ${ }^{6}$ and, by 1998, when a new trade union law was passed, it bore the name of Tanzania Federation of Trade Unions (TFTU). The TFTU was consulted by the government before the enactment of the Trade Unions Act of 1998, a piece of legislation which is praised by some as being in line with the political and economic developments since reform began (see, eg, Mukandala 2001, p 49).

The legislation is important because of the sectors it covers vis-à-vis the economy. The TFTU has also had some programmes which are developmental and which the government would want to run on its own, such as gender sensitisation, human and workers' rights, women/worker participation, anti-child labour

6 Before independence it was the Tanganyika Federation of Labour; in 1964 it turned into the National Union of Tanganyika Workers (NUTA); in 1977, when CCM was born, NUTA was renamed Jumuiya ya Wafanyakazi Tanzania and was one of the party's mass organisations; in 1991 it became the Organisation of Tanzanian Trade Unions - OTTU; in 1995 it was renamed the Tanzania Federation of Trade Unions - TFTU; and today we have TUCTA. 
campaigns and programmes, youth development, and so on (Mukandala 2001, pp 45-46).

Perhaps it is important to point out that CSOs, and specifically CBOs, being what they are, tend to deal more with local government authorities than with the central government. They interact with the latter only when they participate in projects or programmes that it funds but they are right in the picture when it comes to local government activities and concerns because it is at that level that they are competent and that their ingenuity makes a difference.

In examining CSO-state relationships one should take into consideration the point of view of the party seeking the relationship and whether the other party is ready to participate. In some cases there may be mutual benefits, in others one party may reap greater benefits than the other.

It is also important to look at the nature of the state. As we have noted, the possible continuum along which NGOs may move in their relationship with the state can run from a lifeline, through a symbiotic rapport, to a kiss of death. If the regime in place is dictatorial, undemocratic, and violates human rights, close cooperation could well prove to be the 'kiss of death' for the NGO in question. The state will find ways either to emasculate it by donating 'gifts' which will muzzle it or will merely legislate it out of business. If the regime is democratic, observes the rule of law, and requires the cooperation of civil society organisations for the implementation of programmes that are beneficial to the community, the relationship can be a source of life to the NGO. There are other relationship patterns that may, in one way or another, be of mutual benefit.

There are also issues of accountability when NGOs / CBOs engage in service provision - whether funded by donors or by the state. There are two sides to this accountability. The first is the question of whether the NGOs / CBOs will still be accountable to their members and pursue their original goals. How much will they be able to do in order to balance the need to perform the core activities for which they were formed, and the need to have the state on their side in order to draw resources? Secondly, there is the question of the government's accountability to the population and the donor as far as the use of resources is concerned. NGOs/CBOs are not traditionally vehicles for the delivery of services paid for by taxpayers or donor funds that need to be repaid. When something goes wrong government may have a problem accounting for its decisions.

The co-option of NGOs into the provision of services to the state has other repercussions. As noted above, if an NGO helps the state deliver services through activities that are sponsored by donor institutions the state may end up being the net gainer. Donors may feel that they are rebuking corrupt, undemocratic, and inefficient regimes by channelling aid money through CBOs/NGOs but such tactics may backfire, enabling the state to appear to be a benefactor and, 
as a result, keeping it in power longer. As Whitfield (2003, p 383) observes, 'The powerful influence of donor agencies on local organisations, combined with the application of civil society as an area to achieve their objectives of economic and political liberalization, may work towards stabilizing the existing social and political order.'

The issue of identity of CSOs involved in governmental activities must also be put in perspective. Schwartz (2004, p 36) observes that an NGO only remains an NGO if certain conditions are met with regard to its relationship with the government. If this is not the case an NGO may become what he terms a government non-governmental organisation (GONGO), which he defines as a NGO formed by government institutions or agencies. He notes that Knup (1998) provides two criteria for determining when a NGO turns into a GONGO. These are the level of government financing of the activities of the NGO and the number of government employees serving among the workers or as board members of the NGO.

\section{THE DARK SIDE OF CSOS}

CSOs are mostly regarded as good organisations but unfortunately this is not always the case. There is also an underworld of civil society organisations associations with agendas that are politically subversive, economically crippling, and socially disruptive. We know of world wide crime rings in money laundering, drugs, human trafficking, and so on. At the national level there are always associations with agendas that are contrary to the law and which are a menace to civil society and to the state itself. In some cases CSOs have two faces - the good and the bad - depending on the response to their demands on the state, or even on society itself.

In Tanzania police are known to 'break' rings of criminals operating in various underworld spheres of activity. These 'rings' are, in fact, associations, with peers, leaders and chains of command. The relationship between them and the state will definitely be confrontational - except on the rare occasions that the state is an accomplice in such activities.

The other dark side of CSOs relates to a lack of accountability, transparency, and representivity, the three areas of 'good CSO governance'. NGOs all over the world have been accused of policy and operational problems including bureaucratic tendencies, uneconomical duplication, excessively narrow issue advocacy, non-participatory decision-making processes, top-down management, paternalistic attitudes, and so on.

While one can question whether these deficiencies are intentional or not, one cannot rule out the presence of people who join the CSOs with personal 
agendas as their top priority, rather than the agendas of the CSOs themselves. We have heard of 'brief case NGOs' - registered but non-existent. We have heard of target populations complaining of the fact that resources intended for them do not reach them.

In Tanzania the 2002 NGO Act deals with these aspects. While there has been debate about whether private NGOs should be subject to government regulation the fact that there are so many and that considerable resources are channelled through them makes it necessary that provision be made for some kind of accountability and that controls be put in place.

This calls to mind the third scenario put forward by Kiondo (2001) in which, in some instances, the government may feel that national security is at risk. Given that some CSOs are funded from outside the country there must be a way of accounting for such funds to the countries or communities that have donated them - in some donor countries the accounting must be to Parliament. In such situations, unimpeachable financial statements are not only good for the recipient CSOs but for the good name of Tanzania.

NGOs themselves are trying to be more explicit about what they are doing by issuing clearer statements of goals and putting in place stricter financial management, equal opportunities for men and women, and better self-monitoring evaluation processes, opening up to government when necessary and networking with other NGOs.

While states in the developing world do not often give financial support to CSOs it is nevertheless the duty of the government to play a role in distinguishing between genuine CSOs and those which have personalised or fraudulent agendas. By so doing it will help supporters of the CSOs to channel their assistance through those with the right credentials. At the same time, the government has to make sure that CSOs are not used by corrupt state officials for personal gain.

\section{CONCLUSION}

Shivji (2003), in issuing a warning about the close relationship between CSOs and the state, raises a genuine concern. On the one hand CSOs, particularly the intermediary ones, have always faced a dilemma when it comes to deciding how close to the government they should be. On the other activist CSOs have frequently been reluctant to accept government funding, to act as agents of ministries, departments and agencies of government, or even to accept grants to meet staff and overhead costs.

The obvious reason for this reluctance is that they see such involvement as compromising their ability to exert pressure on the government from the outside and perform their legitimate role on behalf of civil society. 
These concerns are legitimate, although CSOs should not automatically assume that the state and its apparatuses are a threat to them and their independence. Given that the citizens' interests are paramount any coalitions, partnerships or cooperation that will better the situation of the people should be taken seriously. However, when agreements are reached the limits must be negotiated in order to achieve a balance between the goals of the CSO and the possible repercussions of the relationship on the interests of the members or intended beneficiaries. On the one hand, the CSO must not lose its identity or change its goal(s), on the other, it must ensure that it is both accountable and transparent.

There is much potential for productivity when government and CSOs join hands and work together, especially in the developing world, where many citizens are not competent enough to participate fully in the broader political processes.

In many instances CSO-government and CSO-donor cooperation makes considerable sense and one way of handling it would be to have a situation in which the government or the donor gives the CSO an unconditional grant, thus enabling the CSO to maintain its independence. Unfortunately, the maxim 'there is no free lunch' looms large in such situations.

One fact that must be acknowledged by both governments and their development partners is that statistics show that in some countries in Africa 3,5 per cent of the economically active population is engaged in the CSO sector. In East Africa the average percentage is 2,5 (Salamon, Solokowski \& List 2003, p 45). In countries where volunteers and donated labour make a considerable contribution to the development effort there is an even greater incentive for the government to cooperate with the CSOs as they can take advantage of the fact that, as records show, more than half of the workers in the CSO sector are volunteers and will therefore not have to be paid by the state (Salamon, Solokowski \& List 2003, p 45). Given the problem of unemployment in most countries, 2,5 per cent of the economically active population cannot be taken for granted. The state must take notice and create a favourable environment for the CSO to do its work.

Another area in which the government may need to intervene is the relationship between the private sector and the CSOs. NGOs with similar resources to those available to the private sector are likely to deliver more, giving them an edge. In an era of public sector reform, where the private sector has been identified as the government's most important partner, and with a variety of cooperation arrangements in place, the private sector has come to see the CSOs as a threat. Both have come to realise that at times they vie for the same resources. CSOs, however, frequently have an advantage over the private sector in that they do not work for profit, even when their efficiency levels are the same. It is likely, therefore, that CSOs will offer better delivery. The challenge for the government, which is the 
regulator, is to see how the two partners in development can be harmonised in order to improve the lives of the citizens.

We would therefore say that the government/state-CSO relationship should be open for negotiation and for renegotiation once an arrangement to work together has been agreed. It is a matter of leaving the window open for mutual adjustments. The government must find ways to allow a CSO to remain a CSO while benefiting from it and CSOs (in their different forms, sizes and activities) need to maintain the distance that is stipulated in the rules within which they operate.

One way of improving the situation for CSOs is for them to campaign for better rules. As Henderson (1997, p 356) notes, the unfortunate irony is that NGOs must come to terms with existing host governmental authorities, often by acceding to repressive policies and accommodating national and local bureaucrats. However, it seems that critics will have to allow some time for the CSOs to fill the gap created in our systems by politically incompetent citizens until such time as the people can control both the CSOs and their government.

Asian Development Bank (ADB). 2000. 'Civil Society and Non-Governmental Organisations'. In To Serve and to Preserve. Hanoi: ADB.

Almond, G \& S Verba. 1963. The Civil Culture: Political Attitudes and Democracy in Five Countries. Princeton, NJ: Princeton University Press.

Baregu, M. 2001. 'Political Competence: Citizens and Subjects, Parochials and Cosmopolitans'. In S S Mushi, M Baregu \& R S Mukandala (eds). Tanzania's Political Culture: A Baseline Survey. Dar es Salaam: Department of Political Science, UDSM.

BAWATA. 1995. Constitution of Baraza la Wanawake Tanzania (BAWATA). Dar es Salaam: BAWATA.

1995b. 'Elimu ya Uraia kwa Wanawake Wapiga Kura na Agenda ya Wanawake Katika Uchaguzi Mkuu wa Mwaka 1995'. Dar es Salaam: BAWATA. Mimeograph.

Bratton, M \& N van de Walle. 1997. Democratic Experiments in Africa: Regime Transitions in Comparative Perspective. Cambridge: Cambridge University Press.

Chazan, N, R Mortimer, J Ravenhill \& D Rothchild. 1988. Politics and Society in Contemporary Africa. London: Macmillan.

Clark, J. 1991. Democratizing Development: The Role of Voluntary Organisations. London: Earthscan. 
Friedman, J. 1988. The Politics of Alternative Development. Oxford: Blackwell.

Dahl, R. 1961. Who Governs. New Haven: Yale University Press.

Deutsch, K W. 1970. Politics and Government: How People Decide Their Fate. Boston: Houghton Mifflin.

Ellis, F. 1988. 'Tanzania'. In C Harvey (ed). Agricultural Pricing Politics in Africa, Four Case Studies. Basingstoke: Macmillan.

Gasarasi, C. 2001. 'Political Competence and Democratic Participation'. In S Mushi, M Baregu \& R S Mukandala (eds). Tanzania's Political Culture: A Baseline Survey. Dar es Salaam: Department of Political Science, UDSM.

Gordon, D L. 1992. 'African Politics'. In A Gordon \& D Gordon (eds). Understanding Contemporary Africa. Boulder Co: Lynne Rienner Publishers.

Henderson, K M. 1997. 'Alternatives to Imposed Administrative Reform: The NGOs'. International Journal of Public Sector Management 10(5).

— 1999. 'A Third-Sector Alternative: NGOs and Grassroots Initiatives'. In K Henderson \& O P Dwivedi (eds). Bureaucracy and the Alternatives in World Perspective. New York: St Martin's Press.

Jjuuko, F W. 1996. 'Political Parties, NGOs and Civil Society in Uganda'. In OlokaOnyango, K Kibwana \& C M Peter (eds). Law and the Struggle for Democracy in East Africa. Nairobi: Claripress.

Kirsten, A. 2004. The Role of Social Movements in Gun Control: An International Comparison Between South Africa, Brazil and Australia. Durban: Centre for Civil Society Research, Research Report No 21.

Kiondo, A. 2001. 'Civil Society: The Origin and Historical Development of the Concept in Tanzania'. Paper presented at a workshop under the Johns Hopkins Comparative Non-Profit Sector Study, Bagamoyo, 30 November to 1 December.

Knup, E. 1998. 'Environmental NGOs in China: An Overview'. China Environmental Series. Woodrow Wilson Center, Environmental Change and Security Project.

Lasswell, H A. 1958. Politics: Who Gets What, When, How. New York: World.

Lissu, T A. 2004. 'Conducive Environment for Whose Development? Globalization, National Economy and the Politics of Plunder in Tanzania's Mining Industry'. In H Kijo-Bisimba, P Rwehumbiza \& S Howard (eds). Globalization: Who Benefits? Annual Human Rights Conference Report, 2003. Dar es Salaam: Legal and Human Rights Centre.

Lofchie, M. 1989. The Policy Factor: Agricultural Performance in Kenya and Tanzania. Boulder, Co and London: Lynne Rienner.

Mercer, C. 2002. 'NGOs, Civil Society and Democratization: A Critical Review of the Literature'. Progress in Development Studies 2(1).

Mhina, A \& R Meena. 2001. 'Non-Profit Impact in Key Fields: Health, Economic 
Improvement and Human Rights Advocacy'. Paper presented at a workshop under the Johns Hopkins Comparative Non-Profit Sector Study, Bagamoyo, Tanzania, 30 November to 1 December.

Mogella, C. 1999. 'The State and Civil Society Relations in Tanzania: The Case of The National NGO Policy'. Research paper submitted for the East African Civil Society Comparative Study.

Mukandala, R S. 2001. 'Trade Unionism in Tanzania: The Case of the Tanzania Federation of Trade Unions (TFTU) and Government'. Research paper presented at the Johns Hopkins Comparative Non-Profit Study Workshop, Bagamoyo, Tanzania, 30 November to 1 December.

Mushi, S, M Baregu \& R. Mukandala (eds). 2001. Tanzania's Political Culture: A Baseline Survey. Dar es Salaam: Department of Political Science, UDSM.

Mwaikusa, J. 1996. 'Party Systems and the Control of Government Powers: Past Experiences, Future Prospects'. In Oloka-Onyago, K Kibwana \& C M Peter (eds). Law and the Struggle for Democracy in East Africa. Nairobi: Claripress.

Olowu, D. 2003. 'Public Administration'. In T Falola (ed). Africa: Contemporary Africa. Durham, NC: Carolina Academic Press.

Ponte, S. 2002. Farmers and Markets in Tanzania. Dar es Salaam: Mkuki na Nyota.

Salamon, L M, S Solokowski \& R List. 2003. Global Civil Society: An overview. Johns Hopkins University: Center for Civil Society Studies.

Schwartz, J. 2004. 'Environmental NGOs in China: Roles and Limits'. Pacific Affair, 77(1).

Shivji, I G. 2003. 'Reflection on NGOs in Tanzania: What We Are, What We Are Not and What We Ought to Be?' HakiElimu Working Papers. Dar es Salaam: HakiElimu.

United Republic of Tanzania. 1992. Report and Recommendations of the Presidential Commission on Single Party or Multiparty System in Tanzania, 1991, Book 1. Dar es Salaam: DUP.

United Republic of Tanzania. 2002. The Non-Governmental Organisations Act, No 24. Dar es Salaam: Government Printer.

United Republic of Tanzania/UNDP. 1998. Human Development Report: Shinyanga Region (Shinyanga: Regional Government).

Van Tuijl, P. 1999. 'NGOs and Human Rights: Sources of Justice and Democracy'. Journal of International Affairs 52 (2).

Welch Jr, C E. 2003. 'Human Rights NGOs and the Rule of Law in Africa'. Journal of Human Rights 2(3).

Whitfield, L. 2003. 'Civil Society as Idea and Civil Society as Process: The Case of Ghana'. Oxford Development Studies 31(3). 